\title{
"Ecological Chain" Cultivation Model of Youth Maker in Universities Based on Needs Analysis
}

\author{
https://doi.org/10.3991/ijet.v14i08.10516 \\ Decao Lin, Lemin Shen $\left({ }^{\square}\right)$ \\ Zhejiang Wanli University, Ningbo, China \\ slmyss a zwu .edu.cn
}

\begin{abstract}
In the new era, "Youth Maker" has become an important force that cannot be ignored in entrepreneurship. However, extant studies on the systematic research about Youth Makers' education in universities are rare, especially the research on the cultivation model under the perspective of college students' entrepreneurship. On the basis of needs analysis, this study conducts interviews on two types of entrepreneurial students and constructs a mathematical model by analytic hierarchy process (AHP) to systematically analyze related data. First, suggestions are proposed, including changing the current cultivation model, perfecting the entrepreneurship course by combining it with professional education, and strengthening platforms and project construction. Then, the suggestions are ranked according to importance. Finally, the "ecological chain" Youth Maker cultivation model is put forward to consistently build a four-year progressive system, construct a curriculum on profession-centered innovation and entrepreneurship, and establish a scientific and efficient incubator. This model can solve the weakness of the existing education model.
\end{abstract}

Keywords - Youth Maker; needs analysis, ecological chain, entrepreneurship

\section{$1 \quad$ Introduction}

The promotion of entrepreneurship, the sharing of entrepreneurial experiences, and the spread of entrepreneurial culture will stimulate a large number of youths, especially college students, to participate in entrepreneurship. Moreover, the market economy requires "nationwide entrepreneurship (Yin \& Liang, 2018)," which is the fundamental source and driver of economic development. The "Global Entrepreneurship Observation" has analyzed from a global perspective that short-term economic development is positively related to entrepreneurship, whereas long-term economic development is even more closely related to entrepreneurial activities(Linton \& Klinton,2019). "Youth Maker" is a group of practitioners with strong practical abilities and strong internal motivation (Rong \& Xiao,2016). They have the impetus to try new things, and they are pioneers in entrepreneurship. With such characteristics and having realized several achievements, they have been regarded a unique group of economic contributors. 
Learning by doing is the core pursuit and basic belief of a maker. The process of translating ideas into reality requires multidisciplinary knowledge and skills, which in turn requires constant experimentation and improvement. Universities are places where knowledge and youth converge, thereby conducive for the cultivation of "Youth Makerss." The State Council of China issued the "Opinions on Strengthening the Implementation of Innovation Driven Development Strategy and Further Promoting the Innovative Development of Mass Entrepreneurship" in 2017, which states the necessity of adhering to the principle of "integration, synergy, and sharing" to promote mass entrepreneurship and innovation. Universities play a key role in this process. Therefore, it is especially important for a university to prioritize the cultivation of "Youth Makerss" who can lead the way toward entrepreneurship in the new era.

\section{State of the Art}

In a broad sense, the original meaning of "Maker" can be explained as "creator" (Luo, 2017), In his book The New Industrial Revolution, Chris Anderson(2012) defined "maker" as a person who thinks innovatively and use new technologies to transform ideas into reality. The word "Youth Makers" was then coined following the definition of "maker."

The research on "Youth Maker" focuses on "maker," "maker space," and "maker moment." Western researchers focus on the construction of maker space, the creation of the education curriculum, and the development of school makers (Nabi, 2018). Colleges and universities are an important base for cultivating talents, especially the Youth Makers, in China. Huang et al. (2015) stated that with the continuous development of the maker movement, college students have become the most creative and active group among Youth Makers. Education reform will become an inevitable trend in higher education in terms of fostering youth makers. Since 2016, the research on youth-maker education has gained popularity in China. Experts define "youthmaker education" as quality education that encourages young people to actively develop their entrepreneurial interests and cultivate their ability to use modern digital tools through teamwork (Liang et al., 2016).

In the research on youth-maker education and entrepreneurship training, scholars believe that maker education emphasizes cultivating students' practical ability, exploration ability, and entrepreneurial innovation ability. Maker education is an educational concept or educational orientation that contributes to the development of students' entrepreneurial abilities (Wang et al., 2015). Thinking set is the key reason for limiting young people's successful entrepreneurship. Youth-maker education can resolve existing problems and stimulate students' entrepreneurial potential (Liang et al, 2016).

Although college youth-maker education has gained attention, the research generally focuses on the promotion of ideas. The research on how to promote college students' entrepreneurship in youth-maker education and studies on the training model are relatively limited. Therefore, the thesis will carry out a systematic research 
on the training model of Youth Makers from the perspective of college students' entrepreneurship.

\section{Methodology}

Any form of talent training model must include "student-centered" implementation in colleges and universities (Fejes, 2018). The cultivation of Youth Makers in higher education should also be based on the development of students, that is, to improve their ability to innovate and help them become qualified "Youth Makers," which serve as the fundamental goal. Therefore, the author holds the view that before the model is designed, a needs analysis of students is necessary to achieve the research goal (Hira \& Hynes, 2018). The needs analysis serves to decompose and refine, and in this process, eliminate contradictions. The premise of the research on the youth maker training model is to fully understand the needs of trainees. Moreover, the understanding process is not only aimed at understanding the process of sorting the problems, the status quo, and the future trends one by one, but also to understand all the effective information in the process. The results of refining and analyzing can provide a strong proof for solving doubts, difficulties, and contradictions, and the process coincides with needs analysis theory. Thus, the author conducted this research by using the method of needs analysis.

\subsection{Research model}

The author fully considers that drawing a conclusion in this study is difficult by using absolute numbers or simply comparing data; the research requires a comprehensive analysis. In addition, the construction of a model should be organically combined with multiple specific schemes. However, before the identification and implementation of the program, an optimization process must clarify its importance.

The analytic hierarchy process (AHP) is an easy way to make decisions in complex and vague problems. It is especially suitable for problems that are difficult to fully quantify. AHP, which was proposed by American operations researcher Professor Saaty in the early 1970 s, is a simple, flexible, and practical multi-criteria decisionmaking method. The survey analyzes the core data in a single way, hence the difficulty of producing comprehensive results. The comparison and optimization of individual programs are necessary for the establishment of the "Youth Maker" training model in colleges and universities. With this purpose, the author builds a model by using AHP to analyze how individual solutions are implemented and how they are integrated for cultivating Youth Makers.

\subsection{Research object}

By adopting needs analysis theory, the author divides the research object into two categories. The first group refers to the "Youth Makers" who have just graduated 
from college less than three years ago or those who will be graduating soon and have successfully started their own business already. For this group of objects, the author selected "Youth Maker" from a university student entrepreneurial park. Three reasons justify why they are selected as the research object. First, they have a deep understanding of the key elements of becoming a Youth Maker, and their personal needs are focused. Second, they have a fresh understanding of the relevant education in colleges and universities because they just graduated or are still enrolled in universities. Third, the entrepreneurial park selected by the author is a municipal-level entrepreneurial park located in a university, which is convenient for data collection. The second group of research object includes college students who have entrepreneurial ideas, desires, and plans. One provincial college is selected for this second group. Three reasons also justify why this university is chosen. First, the university is located in a developed area in China, where a large number of Youth Makers live. Second, the university has good research value because it has offered entrepreneurship courses and has cultivated young makers for a long time, thereby forming certain characteristics and effects. Third, this type of research object has a high degree of recognition among Youth Makers, and they know much about the relevant courses, tutors, platforms, and activities on cultivating entrepreneurship in the said university.

The author named these two groups of objects as "started business" and "want to start a business" and selected 100 objects for each group. The research method uses interviews and questionnaires, and half a year was spent on finishing this research. The aims of the interviews and questionnaires of these two groups differ. A detailed description is shown in Table 1.

Table 1. Details of the interview and questionnaires

\begin{tabular}{|c|c|c|c|c|}
\hline $\begin{array}{l}\text { Type of } \\
\text { object }\end{array}$ & $\begin{array}{c}\text { Questionnair } \\
\text { e collection/ } \\
\text { distribution } \\
\text { number }\end{array}$ & $\begin{array}{c}\text { Number } \\
\text { of } \\
\text { interview } \\
\text { ees }\end{array}$ & Question type & Interview purpose \\
\hline \multirow{7}{*}{$\begin{array}{l}\text { Started } \\
\text { business }\end{array}$} & \multirow{7}{*}{$91 / 100$} & \multirow{7}{*}{31} & $\begin{array}{l}\text { Question 1-5: entrepreneur type, scale, } \\
\text { time, etc. }\end{array}$ & \multirow{7}{*}{$\begin{array}{l}\text { To know more about } \\
\text { these youth makers who } \\
\text { have "started business," } \\
\text { to know about their } \\
\text { education in the } \\
\text { university, their opinion } \\
\text { on entrepreneurship } \\
\text { education, and their } \\
\text { suggestion on the } \\
\text { training model }\end{array}$} \\
\hline & & & $\begin{array}{l}\text { Question 6-9: study performance in } \\
\text { university }\end{array}$ & \\
\hline & & & $\begin{array}{l}\text { Question 10-16: whether the interviewee } \\
\text { has received youth-maker education in a } \\
\text { university }\end{array}$ & \\
\hline & & & $\begin{array}{l}\text { Question 17-22:core competencies of } \\
\text { becoming a youth maker: knowledge, } \\
\text { skills, motivation, and so on }\end{array}$ & \\
\hline & & & $\begin{array}{l}\text { Question 23-27:weakness, problems, and } \\
\text { urgent needs in the training of youth } \\
\text { makers }\end{array}$ & \\
\hline & & & $\begin{array}{l}\text { Interview question 1: What are the core } \\
\text { reasons and key factors that make you a } \\
\text { successful Youth Maker? }\end{array}$ & \\
\hline & & & $\begin{array}{l}\text { Interview question } 2 \text { : If you are a } \\
\text { university president, how do you plan to } \\
\text { cultivate youth makers? }\end{array}$ & \\
\hline
\end{tabular}




\begin{tabular}{|c|c|c|c|c|}
\hline \multirow{8}{*}{$\begin{array}{c}\text { Wanted to } \\
\text { start a } \\
\text { business }\end{array}$} & \multirow{8}{*}{$96 / 100$} & \multirow{8}{*}{36} & $\begin{array}{l}\text { Question 1-4: academic performance in } \\
\text { university }\end{array}$ & \multirow{8}{*}{$\begin{array}{l}\text { From the perspective of } \\
\text { students who want to } \\
\text { become "Youth Makers," } \\
\text { to know more about their } \\
\text { education, their training } \\
\text { experience of being a } \\
\text { Youth Maker, and their } \\
\text { suggestions for the } \\
\text { university }\end{array}$} \\
\hline & & & $\begin{array}{l}\text { Question 5-7: understanding about the } \\
\text { concept of youth makers }\end{array}$ & \\
\hline & & & $\begin{array}{l}\text { Question 8-12: training experience in } \\
\text { youth-maker education }\end{array}$ & \\
\hline & & & $\begin{array}{l}\text { Question 13-20: Weakness, problems, and } \\
\text { urgent needs in the training of Youth } \\
\text { Makers in university }\end{array}$ & \\
\hline & & & $\begin{array}{l}\text { Question 21-26: most wanted skills in } \\
\text { youth-maker education }\end{array}$ & \\
\hline & & & $\begin{array}{l}\text { Question 27-29: the key area that you want } \\
\text { to change in the university }\end{array}$ & \\
\hline & & & $\begin{array}{l}\text { Interview question 1: the most important } \\
\text { factor that inspires your entrepreneurial } \\
\text { ideas }\end{array}$ & \\
\hline & & & $\begin{array}{l}\text { Interview question 2: describe the best } \\
\text { Youth Maker training model }\end{array}$ & \\
\hline
\end{tabular}

\section{$4 \quad$ Data Analysis}

In data collection, the author constructed relevant mathematical models for statistical analysis after the interviews. Let the final display ratio be $N$, the recovery valid data value $P$, and the effective selection value of an option $X$, then $N=X / P$. Considering the questionnaire and interviews are divided into two groups in the analysis, similar problems must be synthesized in the subsequent core data analysis. Thus, the author constructed a mathematical model for the calculation of the proportional value $N$, which was finally embodied. In detail, the sum of the recovered data of the established business is $P 1$, and the sum of the recovered data of entrepreneurial business is assumed to be $P 2$. The effective selection value of the established business is $X 1$, and a valid selection value of the entrepreneurial undertaking is assumed to be $X 2$. If $X 1 / P 1>P 2$, then $\mathrm{N}=(\mathrm{X} 1 / \mathrm{P} 1-\mathrm{X} 2 / \mathrm{P} 2) / 2+\mathrm{X} 2 / \mathrm{P} 2$. If $\mathrm{X} 2 / \mathrm{P} 2>\mathrm{X} 1 / \mathrm{P} 1$, then $\mathrm{N}=(\mathrm{X} 2 / \mathrm{P} 2-\mathrm{X} 1 / \mathrm{P} 1) / 2+\mathrm{X} 1 / \mathrm{P} 1$. These formulas ensure that the data are not spilled and are scientifically effective. The author extracted the core data and performed a unitary analysis according to the above method. The result analysis will be provided as follows.

\subsection{Entrepreneurial reasons are relatively concentrated and consistent with profession}

The survey results show that the key reason why college students start a business is because of the influence from entrepreneurs from the same school, and the ratio $\mathrm{N}$ exceeds $50 \%$. Therefore, the influence of cohorts is crucial for students to become Youth Makers. Moreover, this research found from the interview data that the channels for understanding the relevant information of the entrepreneurs in the same university are diverse. The cultural atmosphere of Youth Makers in the university, the establishment of the role model of entrepreneurs and the influence of entrepreneurial 
activities remarkably inspire the youth makers (Figure 1). In the survey of respondents who have already started their business, findings show that their business projects and their professional degrees have a high goodness of fit at 52.3\%. An increasing number of Youth Makers engaging in entrepreneurial activities based on their respective major is highly possible in the future. Thus, the integration and training model of "profession + entrepreneurship" needs to be improved.

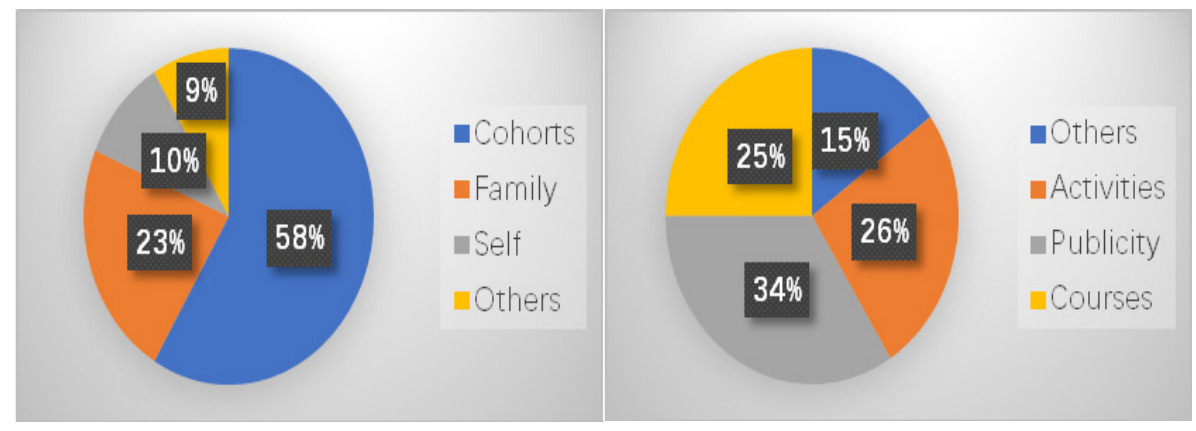

Fig. 1. Analysis of the entrepreneurial reasons and the channels for knowing the relevant information

\subsection{The cultivation of entrepreneurship starts early, but its implementation comes at a later period, and continuity exists between these two periods}

Research shows that the respondents' entrepreneurial willingness is concentrated in their second year of education or earlier, accounting for $69 \%$. However, the implementation of their entrepreneurial behavior, or starting their business, normally occurs in their junior and senior years, accounting for $73 \%$. Moreover, $81 \%$ of respondents opt to continue to develop their original ideas. The cultivation of youth makers, especially entrepreneurial awareness, should begin early in university education. However, the specific entrepreneurial skills, knowledge, and ability need to be taught only after the students have developed strong motivation and knowledge base. Moreover, the support for entrepreneurial projects needs to be continuous such that the constant improvement of entrepreneurial ideas ultimately helps the students to achieve their goals.

\subsection{Awareness of core competence is concentrated and extensive}

In the questionnaire, the authors designed a particular multiple-choice question about core competence and the key elements of entrepreneurship. The hope was that, through data analysis, the support platform for cultivating the Youth Makers will be consistent with the needs of the cultivators in terms of knowledge, ability, and quality.

The survey data show that the relevant choices are concentrated. The statistics of more than one-fourth of the total selection are shown in Table 2. According to the data, in the eyes of students, core competence and the key elements of entrepreneurship are highly comprehensive. 
Examples are the professional knowledge directly offered through the university curriculum, the entrepreneurial tutor, the relevant humanistic qualities, characteristics that need to be indirectly cultivated, and the related elements that are not in the traditional functional scope of the university, such as support funds and project search, among others. In the near future, the youth makers' training model should be able to meet the core competence and the key elements for cultivating students in a multidimensional and diverse manner. This undertaking requires the university to update the traditional model for innovation.

Table 2. Summary of core competence and key elements of entrepreneurship from the perspective of youth makers, with a total exceeding $25 \%$

\begin{tabular}{|c|c|c|}
\hline Type & Competence or elements & $\begin{array}{c}\text { Proportion } \\
\text { (N) }\end{array}$ \\
\hline \multirow{4}{*}{$\begin{array}{l}\text { Core competence to become a } \\
\text { youth maker }\end{array}$} & To become a pioneer & $36.3 \%$ \\
\hline & $\begin{array}{l}\text { A comprehensive understanding of entrepreneurial } \\
\text { knowledge and skills }\end{array}$ & $33.7 \%$ \\
\hline & $\begin{array}{l}\text { A thorough understanding of relevant professional } \\
\text { knowledge }\end{array}$ & $33.4 \%$ \\
\hline & Good communication and collaboration skills & $29.5 \%$ \\
\hline \multirow{4}{*}{$\begin{array}{l}\text { Key elements for a successful } \\
\text { youth maker }\end{array}$} & Marketable and realistic projects & $56.8 \%$ \\
\hline & Sufficient initial funding source & $46.4 \%$ \\
\hline & Good teamwork & $41.9 \%$ \\
\hline & A tutor who can provide practical guidance & $37.5 \%$ \\
\hline
\end{tabular}

\subsection{Existing training has not been systematically implemented}

Knowing the respondents' acceptance of the training and education condition of entrepreneurship is important in analyzing their effectiveness and influence. The sorted data show that most of the youth makers or to-be youth makers have received relevant training and education. However, problems exist, including variety of training forms, differences of each stage, and arbitrariness of the training models (Table 3). These problems indicate that the training or education the students have received is somewhat unsystematic. Such kind of education approach cannot provide the comprehensive knowledge needed by the youth makers, especially for motivating them. Moreover, the random combination and selection of training materials with the training model can hinder effective teaching. Therefore, thorough consideration is required when constructing a new training model. 
Table 3. Accepting relevant training and education statistics

\begin{tabular}{|c|c|c|c|c|c|c|c|}
\hline \multicolumn{2}{|c|}{$\begin{array}{l}\text { Accepting relevant } \\
\text { training and education } \\
\text { statistics (N) }\end{array}$} & \multicolumn{2}{|c|}{$\begin{array}{c}\text { Initially received time } \\
\text { statistics on relevant } \\
\text { training and education } \\
\text { (N) }\end{array}$} & \multicolumn{2}{|c|}{$\begin{array}{l}\text { Most relevant training } \\
\text { and education type } \\
\text { statistics (N) }\end{array}$} & \multicolumn{2}{|c|}{$\begin{array}{c}\text { Channel statistics for } \\
\text { initial training and } \\
\text { education consultation } \\
\text { (N) }\end{array}$} \\
\hline Accepted & $>1$ year & Freshman & $16.5 \%$ & $\begin{array}{l}\text { Relevant } \\
\text { activities }\end{array}$ & $32.6 \%$ & Mass media & $31.8 \%$ \\
\hline \multirow{4}{*}{$1.3 \%$} & \multirow{4}{*}{$6.2 \%$} & Sophomore & $31.8 \%$ & $\begin{array}{l}\text { Relevant } \\
\text { lectures }\end{array}$ & $26.7 \%$ & $\begin{array}{l}\text { Recommend } \\
\text { ed by } \\
\text { teachers }\end{array}$ & $30.2 \%$ \\
\hline & & Junior & $32.3 \%$ & $\begin{array}{l}\text { Special } \\
\text { courses }\end{array}$ & $21.4 \%$ & $\begin{array}{l}\text { Recommend } \\
\text { ed by friends } \\
\text { or } \\
\text { classmates }\end{array}$ & $22.7 \%$ \\
\hline & & Senior & $18.3 \%$ & $\begin{array}{l}\text { Related } \\
\text { competitions }\end{array}$ & $16.2 \%$ & \begin{tabular}{|l|} 
In the \\
original \\
training plan
\end{tabular} & $11.6 \%$ \\
\hline & & \begin{tabular}{|l|} 
After \\
graduation
\end{tabular} & $1.1 \%$ & Others & $3.1 \%$ & Others & $3.7 \%$ \\
\hline
\end{tabular}

\subsection{Suggestions for improvement are almost the same}

The main purpose of the interview is to know more about the needs of Youth Makers through face-to-face communication. By understanding their needs, a suitable training model can be constructed (e.g., a doctor can prescribe the correct medicine). The findings from the interview show that the respondents had their own suggestions on improvement. The first set of suggestions is the implementation of a systematic training model and the formulation of a characteristic model with the support of relevant policies and funds. The second set of suggestions involves changing the simple curriculum to one that can meet the requirements of the students, that is, the attempt to combine professional learning and entrepreneurship learning and the provision of practical knowledge and skills that go beyond theories. The third set of suggestions is the employment of tutors well adept in entrepreneurship, especially those who can provide practical guidance to specific projects. The fourth set of suggestions is the creation of a school-owned platform that can provide practical assistance, such as funding, technologies, and services. The last set of suggestions is to change the current situation of students' education and training that is viewed as neglectful of the specific projects or individuals. In other words, the students are calling for detailed implementation policies.

\subsection{Model analysis}

In conducting this research, the target layer is relatively clear, that is, "building a suitable Youth Maker training model in the university." The setting of the criteria layer comes from the analysis of the core data. The author has established five layers, namely, system construction, professional integration, training start time, factor conformity, and literacy targeting. On the basis of the single analysis mentioned above, the author also proposed four improvement plans. With the guidance of AHP, 
three plans are found to be appropriate and accurate. Thus, the author generated three plans according to the actual situation, namely, to change the current status of limited training, to improve the "profession+entrepreneurship" curriculum, and to strengthen the platform and the methods of project construction. The hierarchical model is shown in Figure 2.

First, we assign weights to BI-B5 of the criteria layer according to the principle of AHP, and two of the criteria are compared with one another. The established matrix is shown in Table 4. We also evaluate the solution layer and establish a matrix at the same time (Table 5). Then, we calculate the consistency to verify the accuracy of the findings (Table 6). The consistency of B1-B5 was less than 0.1, which is acceptable.

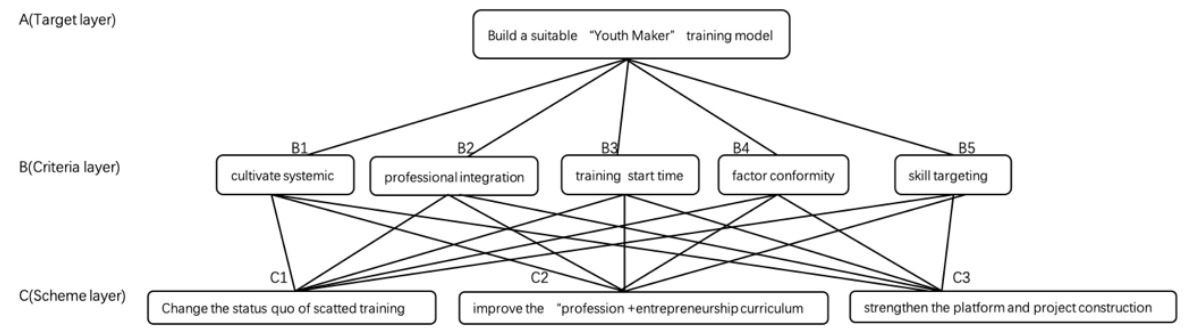

Fig. 2. Hierarchical structure model

Table 4. Judgment matrix of the criteria layer

\begin{tabular}{|l|c|c|c|c|c|}
\hline \multicolumn{1}{|c|}{ A } & B1 & B2 & B3 & B4 & B5 \\
\hline B1 & 1 & 7 & 7 & 5 & 5 \\
\hline B2 & $1 / 7$ & 1 & 7 & 1 & 1 \\
\hline B3 & $1 / 7$ & $1 / 7$ & 1 & $1 / 7$ & $1 / 6$ \\
\hline B4 & $1 / 5$ & 1 & 7 & 1 & 1 \\
\hline B5 & $1 / 5$ & 1 & 6 & 1 & 1 \\
\hline
\end{tabular}

Table 5. Judgment matrix of the scheme layer criteria layer

\begin{tabular}{|c|c|c|c|c|c|c|c|c|c|c|c|}
\hline B1 & C1 & C2 & C3 & B2 & C1 & C2 & C3 & B3 & C1 & C2 & C3 \\
\hline $\mathrm{C} 1$ & 1 & 7 & 9 & $\mathrm{C} 1$ & 1 & $1 / 6$ & 3 & $\mathrm{C} 1$ & 1 & 7 & 9 \\
\hline $\mathrm{C} 2$ & $1 / 7$ & 1 & 3 & $\mathrm{C} 2$ & 6 & 1 & 7 & $\mathrm{C} 2$ & $1 / 7$ & 1 & 3 \\
\hline $\mathrm{C} 3$ & $1 / 9$ & $1 / 3$ & 1 & $\mathrm{C} 3$ & $1 / 3$ & $1 / 7$ & 1 & $\mathrm{C} 3$ & $1 / 9$ & $1 / 3$ & 1 \\
\hline B4 & $\mathrm{C} 1$ & $\mathrm{C} 2$ & $\mathrm{C} 3$ & $\mathbf{B} 5$ & $\mathrm{C} 1$ & $\mathrm{C} 2$ & $\mathrm{C} 3$ & & & & \\
\hline $\mathrm{C} 1$ & 1 & 7 & 3 & $\mathrm{C} 1$ & 1 & 3 & 5 & & & & \\
\hline $\mathrm{C} 2$ & $1 / 7$ & 1 & 1 & $\mathrm{C} 2$ & $1 / 3$ & 1 & 4 & & & & \\
\hline $\mathrm{C} 3$ & $1 / 3$ & 1 & 1 & $\mathrm{C} 3$ & $1 / 5$ & $1 / 4$ & 1 & & & & \\
\hline
\end{tabular}

Table 6. Consistency of the criteria layers B1-B5criteria layer

\begin{tabular}{|l|c|c|c|c|c|}
\hline & B1 & B2 & B3 & B4 & B5 \\
\hline $\mathrm{CR}$ & 0.0772 & 0.0961 & 0.0772 & 0.0772 & 0.0825 \\
\hline
\end{tabular}


Finally, the total result of hierarchical sorting is obtained (Table 7), and the consistency of the total order of the hierarchy is tested. The calculated result is $\mathrm{CR}=0.0804$, which is less than 0.1 . The final result can then be adopted.

Table 7. Hierarchical total ordering criteria layer

\begin{tabular}{|c|c|c|c|c|c|c|c|}
\hline \multirow{2}{*}{\multicolumn{2}{|c|}{\begin{tabular}{|r|} 
Criteria layer \\
Criteria layer weight
\end{tabular}}} & B1 & B2 & B3 & B4 & B5 & \multirow{2}{*}{$\begin{array}{c}\text { Total sort } \\
\text { weight }\end{array}$} \\
\hline & & 0.5677 & 0.1313 & 0.0323 & 0.1373 & 0.1314 & \\
\hline \multirow{3}{*}{$\begin{array}{l}\text { Scheme } \\
\text { layer single } \\
\text { sort weight }\end{array}$} & $\mathrm{C} 1$ & 0.7854 & 0.7504 & 0.7854 & 0.6941 & 0.6267 & 0.6714 \\
\hline & $\mathrm{C} 2$ & 0.0658 & 0.1713 & 0.1488 & 0.1315 & 0.2797 & 0.2485 \\
\hline & C3 & 0.1488 & 0.0782 & 0.0658 & 0.1744 & 0.0936 & 0.0801 \\
\hline
\end{tabular}

According to the final ranking weights calculated by AHP, "changing the status quo of scattered culture" is the most important factor and thus should be improved. "Perfect combination of profession and entrepreneurship curriculum" ranks second, and "strengthening platform and project construction" ranks third. This result provides meaningful suggestions for reconstructing the youth maker training model in universities.

\section{Model Construction Based on Needs Analysis}

From the previous research, drawing conclusions about the individual Youth Maker is not difficult, but the entrepreneurial attempt or the success of the entrepreneur must be based on one's own subjective consciousness. In terms of university, simply relying on students' personal behavior is not an efficient approach Hayter, 2017. The University should function as a guide and construct a platform to motivate students, deliver knowledge, build a team, and develop projects. In local and foreign universities, the training model of youth maker is adopted to local conditions and thus manifests differently. On the basis of the AHP analysis, changing the current status of the scattered training model is the most effective one. Thus, the author puts forward the concept of "ecological chain" for constructing the training model of youth maker. In this "ecological chain," we will string together "teaching" and "learning," "curriculum" and "activities," "profession learning" and "entrepreneurial learning," and "tutoring" and "project incubating." A detailed description of this model is discussed in subsequent sections.

\subsection{Construct a progressive four-year cultivating model}

The cultivation of youth makers in higher education cannot be separated from the original training system, that is, they cannot be "self-contained." However, from the perspective of needs analysis, the problem of "either concentrating or being too fragmented" needs to be solved. In addition, the "ecological chain" training itself requires a systematic, coherent, and targeted approach. Consequently, a progressive four-year cultivation model is proposed. 
The progressive four-year cultivation model specifically refers to the cultivation of students' ability to innovate and start their own business. Many factors should be considered when constructing this model, including psychological maturity, professional quality growth factors, social understanding level, and entrepreneurial proficiency of students. In this model, professional teaching and entrepreneurship training should be organically combined, and four stages with different aims can be carried out for entrepreneurship education (Figure 3).

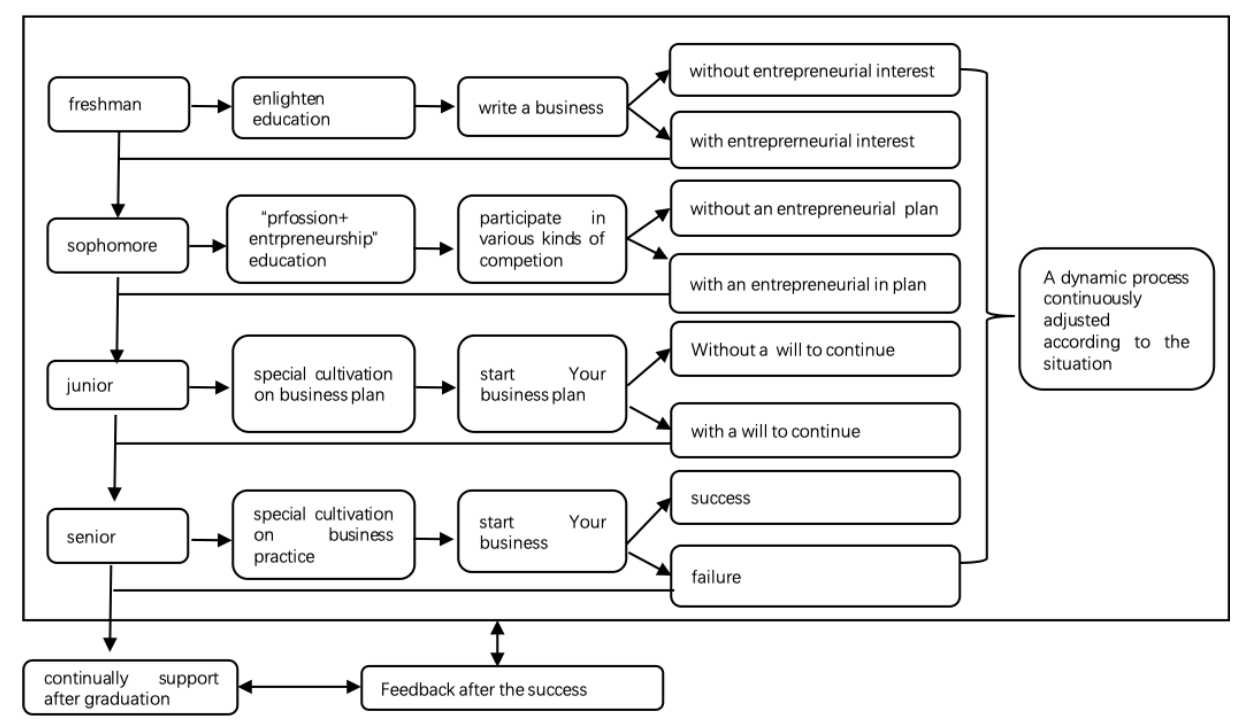

Fig. 3. Progressive four Hierarchical Progressive four Progressive four-year cultivating model

\subsection{Create a special course on "profession + entrepreneurship"}

In the subject of university education, professional education must be included. From another viewpoint, as shown by the AHP analysis above, the youth makers' entrepreneurial projects are consistent with their profession in the university. A high demand for professional entrepreneurship education exists; that is, without professional teaching, the entrepreneurial cultivation model can be likened to a tree without roots. To some extent, professional teaching is the base of this model, and creating a special course on the combination of professional teaching and entrepreneurship is the key step in this model.

In the creation of a special course, the duties between the school and its faculty should first be clearly delineated. The school should play the leading role and conduct an overall planning. Meanwhile, each faculty should establish one's own entrepreneurial organization to implement the respective curriculum. In the design of entrepreneurship courses, we should standardize the macro requirements, such as the minimum credit requirements, the minimum class requirements, among others, and allow the faculty to strategize. With the "results-oriented" model, the faculty can also improve themselves. 
In the construction of the course, we should also clearly differentiate between entrepreneurial courses and professional courses. Entrepreneurial courses focus on the tutor's function, which is to provide practical guidance and foster the environment for successful business projects. As a result, cultivating a successful tutor team becomes the key role in creating the special course. The tutor can provide guidance in four ways. The first is individual guidance, in which the student identifies the problem, and the tutor provides a targeted suggestion. The second is "consultation" guidance, in which tutors conduct collective consultations on difficult problems. The third is giving instructions, which is targeted by solving the general problems proposed by students. The fourth is "companion" guidance. According to the different characteristics of college students' entrepreneurship, the tutor tracks their processes and conducts full guidance.

\subsection{Building a scientific and efficient "incubator"}

One of the most important goals in training Youth Makers is to encourage students to truly participate in entrepreneurship. The entrepreneurial process from "have not been done" to "have done" is not only dependent on education and guidance but also on actual incubation and full support. This process intrinsically differs from other types of talent cultivation. The back end of the "ecological chain" training model is therefore the formation of a "results-oriented" model, in which the training results can feed the cultivation of the youth maker model. Therefore, building a scientific and efficient "incubator" is imperative. In the process of constructing this "incubator," colleges and universities must look into their own advantages, an approach that differs from entrepreneurial incubation or support platform built by the government, companies, or other organizations. Schools should play the leading role in constructing this "incubator." Overall planning by schools should consider organizing a scientific and efficient "incubator" to help the students to incubate knowledge to technology. This incubator should have several features.

First, the incubator should have a powerful service function, which can organize all the steps of entrepreneurship from the beginning to the establishment. In particular, it should be able to provide various kinds of service, such as project selection, team formation, personnel management, legal support, enterprise core technical support, business planning, logistics management, financial management, risk control, among others. Colleges and universities can provide professional services in the early stage, gradually integrate resources inside and outside the school, and slowly realize the balance of income or profit of the service. Even entrepreneurial service itself can be operated as a business project. Second, the incubator function is strongly recognized by universities and faculties. The degree of recognition is not only at the level of consciousness but also from a technical perspective. The "incubator" should provide a platform for forming initial entrepreneurial knowledge, improving entrepreneurial ability, and transforming professional project and competition. As a result, it will help realize the integration of projects, personnel, teams, and funds. For example, a competition project involving science and engineering has certain entrepreneurial potential. Take this competition project as an incubator, and it will provide the 
platform for students who have already been cultivated to participate in personnel recruitment, team formation, and enterprise incubation. Fourth, the incubator should also gradually pay attention to the teacher's project transformation. With the support from all the faculties and the top level, designing incubators at the school level is recommended accordingly.

\subsection{Focus on incubating quality entrepreneurial projects}

In the cultivation of youth makers, we cannot ignore the role of "model," because Youth Makers themselves are "a group of people who come together for the same dream," and it naturally needs motivation. In the practice of cultivating youth makers, universities should strive to cultivate a large group of youth maker models and publicize their achievements to vigorously create a "glorious campus culture." According to the "Annual Report on the Entrepreneurship of Graduates of the Year," the university can lead the survey of at least 30 youth makers and conduct in-depth interviews with them. A school-wide publicity campaign can serve as good examples in fully motivating young students.

\section{Conclusion}

On the basis of the investigation of two groups of college students, this thesis constructs the data model by using AHP and carries out the optimization of the importance of the scheme. The model proposed an "Eco-chain" Youth Maker cultivation model in the university. The model aims to solve the problems of universities, namely, unsystematic cultivation of youth makers, untargeted curriculum, and somewhat poor platform service. To some extent, certain practicality and operability have been considered. In conclusion, it can be summarized as follows:

- Systematically construct an "ecological chain" training model to solve the problem of integrating youth-maker education and entrepreneurship education;

- Establish the "four-year consistent system" to make the current model systematic;

- Create a special course that combines professional education and entrepreneurship education to promote youth-maker education;

- Provide practical assistance, such as related funds, technology, and services by creating an efficient "incubator"

- Through the efforts to incubate high-quality entrepreneurial projects, we will address individuals and projects ignored by the current approach.

\section{$7 \quad$ References}

[1] YM Yin and WQ Liang, Richard Weber: Evaluating Entrepreneurship Education, Entrepreneurship Education, 2018, vol, 1(1-4), pp.125-129. https://doi.org/10. $\underline{1007 / \mathrm{s} 41959-018-0005-8}$ 
[2] G Linton and M Klinton, University Entrepreneurship Education: a design thinking approach to learning. Journal of Innovation and Entrepreneurship, 2019, vol, 8(1), pp.3-8. https://doi.org/10.1186/s13731-018-0098-z

[3] HL Rong and L Xiao, Cultivating Creativity by Scaling up Maker Education in K-12 Schools, Modern Educational Technology, 2016, vol, 20(3), pp.56-62.

[4] Luo, J. A review of maker cultivation in higher education in the era of big data, Journal of Heihe Academy, 2017, vol, (11), pp.111-112.

[5] Chris, A., Makers: The New Industrial Revolution. New York: Crown Business, 2012.

[6] G Nabi, A Walmsley, F Liñán, I Akhtar, and C Neame, Does entrepreneurship education in the first year of higher education develop entrepreneurial intentions? The role of learning and inspiration. Studies in Higher Education, 2018, vol, 43(3), pp.452-467. https://doi.org/10.1080/03075079.2016.1177716

[7] Z. Huang, G. Zhao, and Y. Hong. A research on the development model of maker education in higher education, Research in Higher Education of Engineering, 2015, vol,04, pp.33-37.

[8] Liang, X. A study on the combination of maker education and higher education reform, Industry and Science Tribune, 2016, vol,15, pp.38-46.

[9] Wang, Y. Wang, Y. and Bao, X. Maker education continuity: activating innovative genes in the age of mass creation, Modern Distance Education Research, 2015, vol, 05, pp.38-49.

[10] A Hira, and M Hynes, People, means, and activities: a conceptual framework for realizing the educational potential of makerspaces. Education Research International, 2018, 1-10. https://doi.org/10.1155/2018/6923617

[11] A Fejes, M Nylund, and $\mathrm{J}$ Wallin, How do teachers interpret and transform entrepreneurship education?. Curriculum Studies, 2018, vol, 2, pp.1-13.

[12] CS Hayter, R Lubynsky, and S Maroulis, Who is the academic entrepreneur? The role of graduate students in the development of university spinoffs. J Technol Transf, 2017, vol, 42(6), pp.1237-1254. https://doi.org/10.1007/s10961-016-9470-y

\section{Authors}

Decao Lin is a research assistant in the Department of Students Affairs, Zhejiang Wanli University, Ningbo, 315100 China (46034132@qq.com).

Lemin SHEN is an associate professor in the Foreign Languages College, Zhejiang Wanli University, Ningbo, 315100 China. (slmyss@zwu.edu.cn).

Article submitted 2019-01-11. Resubmitted 2019-03-17. Final acceptance 2019-03-21. Final version published as submitted by the authors. 